\title{
SOLUTION OF GENERAL AND PREVENTION OF ECOLOGICAL PROBLEMS OF STARA PLANINA MOUNTAIN AS POTENTIAL OBSTACLES TO THE DEVEOPMENT OF RURAL TOURISM
}

\author{
Mladjan Maksimović ${ }^{1}$, Tatjana Janovac ${ }^{2}$, Darjan Karabašević3 , Miodrag Brzaković ${ }^{4}$ \\ *Corresponding authorE-mail: mladjan.maksimovic@mef.edu.rs
}

A R T I C L E I N F O
Original Article
Received: 12 March 2018
Accepted: 22 May 2018
doi:10.5937/ekoPolj1802531M
UDC 502/504:338.48-44(1-22)
(497.11 Stara planina)

Keywords:

Stara planina, rural tourism, potential obstacles, ecological

JEL: Q10, Z30, Z32

\begin{abstract}
A B S T R A C T
The development of rural tourism positively affects the economic development of rural communities, but the very pace of its development often results in negative effects on the environment. Uncontrolled rural tourism development, without an adequate planning system, can greatly endanger the entire ecosystem of a destination. The aim of this paper is to determine how much the development of rural tourism on Stara Planina Mountain depends on the solution of general and prevention of ecological problems. A method that allows the cause-effect relationships between these phenomena is a linear regression analysis. This analysis best describes the quantitative dependence between the variations of the observed phenomena in real conditions. It represents the means that enable us to evaluate and predict the values of the dependent variable for the desired values of the explanatory variable. In other words, the main issue is rural tourism on Stara Planina Mountain, which depends on the solution of general and prevention of environmental problems.
\end{abstract}

(C) 2018 EA. All rights reserved.

\section{Introduction}

The main resource of rural tourism development is natural environment. It is estimated that more than half of the total tourist demand in the world is directed towards natural wealth and areas of untouched nature.

1 Mladjan Maksimović Ph.D., Assistant Professor, Faculty of Management, Economics and Finance, University Business Academy in Novi Sad, Jevrejska Street no. 24, 11000 Belgrade, Phone: +381 64 1479793, E-mail: mladjan.maksimovic@mef.edu.rs

2 Tatjana Janovac Ph.D., Assistant Professor, Faculty of Management, Economics and Finance, University Business Academy in Novi Sad, Jevrejska Street no. 24, 11000 Belgrade, Phone: +381 63 7235232, E-mail: tatjanastanojlovic@yahoo.com

3 Darjan Karabašević Ph.D., Assistant Professor, Faculty of Management, Economics and Finance, University Business Academy in Novi Sad, Jevrejska Street no. 24, 11000 Belgrade, Phone: +381 60 3383333, E-mail: darjan.karabasevic@mef.edu.rs (https://orcid. org/0000-0001-5308-2503).

4 Miodrag Brzaković Ph.D., Full Professor, Faculty of Management, Economics and Finance, University Business Academy in Novi Sad, Jevrejska Street no. 24, 11000 Belgrade, Phone: +381 64 1820103, E-mail: miodrag.brzakovic@mef.edu.rs 
In the last few decades, rural tourism has been followed by many unwanted consequences, mostly ecological ones. An uncontrolled development of rural tourism without an adequate planning system can significantly jeopardize the entire ecosystem of a destination. Inadequate disposal of waste during tourist activities can lead to contamination of soil and water. Also, the development of rural tourism leads to increased traffic, which inevitably affects pollutant emissions, increases the greenhouse effect, noise, but also energy consumption.

Although the modern world is confronted with responsibility and awareness that the planet must be preserved for the present and future generations, it is necessary to reconcile the needs of people with the preservation of nature. The obligation of today's generations is to leave to the posterity the best chance possible to live and survive. Therefore, the need for implementation of measures aimed at reducing the wasteful consumption of resources, increasing productivity with maximum respect to the environment and implementation of environmental policy is imposed (Kostić et al., 2014).

Stara Planina has huge natural potential for tourism development. It has very rich biological, geological and cultural heritage. Considering the fact that it mostly extends along the border belt with neighboring Bulgaria, Stara Planina has not yet developed as a tourist attraction of Serbia. This fact has mostly enabled the preservation of its natural and social characteristics (Stankov et al., 2010). Natural beauties of Stara Planina, in combination with culture, tradition, gastronomic specialties and music of Eastern Serbia, can become a recognizable tourist brand that would improve the image of the region and the entire state (Maksimović et al., 2015b). In the development of rural tourism, special attention should be paid to the protection of the environment and its resources. Also, we have to emphasize the importance of responsible business activities, which should be conducted in cooperation with local authorities and with the residents in order to meet local needs and create the benefits for them.

\section{Literature review}

Tourist destination of Stara Planina, as stated by Nikolić et al. (2015), is an attractive area with great perspective for entering the world tourist scene.

In the last few decades, rural tourism, as well as commercial tourism, has been followed by many environmental, social and cultural unwanted consequences, and hence there was created the need to frame these activities by the concepts of sustainable development. The modern world is responsible for saving the planet for present and future generations, and therefore it is an imperative to harmonize the needs of people with the preservation of nature. It is the obligation of today's generations to leave to the posterity at least what they had. Present generations can claim resources and healthy living, but they should not jeopardize the same right for the generations to come (Marković \& Pejanović, 2012; Jovičić, 2002).

Sustainable tourism represents an economic branch that has a minimal impact on the local culture and the environment. At the same time, it enables new jobs, the 
adequate salaries, and the protection of the ecosystems. There is no unique definition of sustainable rural tourism development. However, we could say that the sustainable development of rural tourism means the respect of the general principles of sustainable development and ethics, which applies to all the participants in the tourism process. Although the concern for sustainable development represents the basis for modern planning and management of tourist destinations, the question is how much it is applied in practice (Ruhanan, 2012).

Sustainable rural tourism development, based on an integrated approach, implies equally emphasis on the following components (Jovičić, 2000):

- Preservation of the environment,

- Affirmation of social integrity,

- Cultivating cultural characteristics of the local population,

- Optimally meeting the tourist needs,

- Making economic profit.

The basis for the mentioned activity is certainly the quality of the environment, the social integrity and the cultural identity of the rural areas. Respect of the sustainable development concept represents a great contribution to their affirmation. It enables economic profit and meeting the needs of tourists. Bearing in mind the mentioned facts, we could even say that sustainable rural tourism represents an integral and complex development of tourism that simultaneously ensures the achievement of heterogeneous goals, where none of them should be dominant in relation to others (Jovičić, 2000).

The basic dimensions of tourism sustainability are as followed:

- Ecological sustainability - the development of tourism does not cause irreversible changes in the ecosystem of the destination. It is the most widely accepted dimension since there is a clear need around the world to protect natural resources from the negative impact of tourism activities.

- Social sustainability - the ability of the local community to accept tourism (both the tourism industry and the tourists themselves) without creating social discord.

- Cultural sustainability - a particular local community is able to retain (preserve) or adjust its own characteristic cultural line despite the pressure of the so-called "tourist culture" of visitors.

- Economic sustainability - the level of economic profit from tourism that is sufficient to provide a certain income for the local community and to cover all the costs of the specific measures taken in order to satisfy tourists' needs (even though the prerequisite for economic sustainability is the attractiveness of a particular area and the understanding the importance of a high quality service; a destination cannot be economically viable without the competitive position on the world market) (Popesku, 2002). 
Negative effects of the tourism activities that can jeopardize ecological sustainability are as followed:

- air pollution,

- water pollution,

- noise,

- different electromagnetic radiations etc.

One of the consequences of the environmental pollution caused by tourism activities is diseases, which represent the most difficult form of deterioration of the life quality. According to Mladenović (2015), the modern human population is concerned about the safety of air, drinking water and food, but also about materials that can represent the risk for health (Mladenović, 2015). Toxic substances in air and food can cause a variety of health disorders for humans and animals, from the change of biochemical and physiological status to reproductive and pathological changes, and in extreme cases they cause death. Given that the presence of contaminants is an inevitable characteristic of the environment, the risks they bring can be limited, but not completely eliminated.

The ecological aspect of sustainable development, according to Miletić et al. (2015), brings great changes in an ecological system that encompasses the ecosystem integrity and concern for it. This is, in fact, the protection of the environment, which means that sustainable development can be realized smoothly with the constant development of environmental awareness. Sustainable development through this dimension includes the care for the preservation of water, air and soil quality, preservation of flora, fauna and human health, which is the main condition for sustainable business (Miletić et al., 2015).

Rural tourism can also be useful for ecological sustainability, as it can be the reason for the protection and preservation of natural habitats and wildlife, precisely because of their value as a tourist resource. It also increases tourist awareness about environmental issues, provides new and upgrades the existing infrastructure. In this way, it can become a source of additional income for agricultural producers.

According to Kalač (2013), the number of tourists included in this type of tourism is growing and increasing in all rural areas. In order to attract tourists in these areas (with a goal to create additional income, among other things), it is necessary for farmers and villagers to offer a wide range of activities and services. Adoption of this concept of rural tourism includes not only tourism in rural households or agritourism, but also breaks in nature, excursions to rural areas and longer staying (Kalač, 2013).

Gašić et al. (2015) state that the development of tourism in rural areas aims to solve a number of economic issues related to the depopulation caused by migration of inhabitants to urban regions. Improving life conditions and environmental protection increase the stability of the working-age population, which enables migration in the opposite direction, from urban to rural zones. Such activities contribute to the economic development of rural areas and have an impact on future development of the economy of the whole region (Gašić et al, 2015). 
The main economic significance of this type of tourism lies in the tourists' purchases in the areas they visit, because apart from accommodation services, there are also events, festivals, recreation, production and sale of handicrafts and agricultural products. For this reason tourist demand is increasingly seeking to avoid tourist destinations oriented toward one place. It aims to return to the traditional and typical values and authenticity, where they can find new tourist products with new environmental, natural and social parameters (Sanagustín Fons et al., 2011). Therefore, the money that tourists earn in they own counties they spend in a particular tourist destinations. In this way, it is being created certain economic effect on the economy, both in the areas from which tourists come and in the areas they visit (Unković and Zečević, 2006).

Money that tourists spend has direct and indirect effects on the economy of local areas. Some of the most important impacts of rural tourism on the economy are se followed (Maksimović et al, 2015a):

- Impact on GDP and national income;

- Impact on the development of activities that belong to the tourist economy;

- Impact on the balance of payment of a country;

- Impact on the employment and life standard;

- Impact on the investment activities and the structure of investments;

- Impact on faster development of poorly developed countries and areas.

Beside the direct impacts on the economy, the indirect impacts of rural tourism deserve considerable attention. Money that tourists spend is directly linked to the activities of tourist industry, and it, to some extent, affects all economic and non-economic activities. This creates new jobs that automatically reduce unemployment, which has been identified as one of the most important benefits of rural tourism (Inskeep, 1991).

In order to achieve economic goals, we should strive to provide quality services, as this ensures optimal satisfaction of the domestic and foreign tourists' needs. On the other hand, meeting the tourists' needs leads to the realization of favorable economic results of all participants in the business process (Muhi, 2013).

In 2002 in Johannesburg, Serbia presented tourism as an example of sustainable development; in other words, it was presented tourism based on the concept of sustainable development (Živković, 2013). According to Živković, the aim of the program is to develop a legal and political framework to support rural economy diversification through tourism and contribute to the achievement of the millennium development goals at the national level, that is to improve connectivity and organization of rural tourism by improving the capacity of local service providers, as well as local production in line with national strategy. Key activities aimed at achieving goals are as followed (Živković, 2013): 
- Development of the National Master Plan for the development of rural tourism and the national program for rural development;

- Providing guidelines for public investments with the aim to create national and international partnerships between the public, civil and state sectors;

- Strengthening capacities of entrepreneurs in rural tourism, as well as capacities of tourist organizations and citizens' associations;

- Promotion of an innovative approach to the development through local agency groups and tourist organizations, as well as providing special support to local projects through a joint UN programs for sustainable tourism and rural development.

Considering that the goal of each tourist destination in modern tourism is to create a unique identity (a difference in relation to competition), precisely this fact will be the basis for growth and development of the tourist destination of Stara Planina in the competitive market (Gašić et al., 2013).

\section{Materials and methods}

The aim of this paper is to determine how much the development of rural tourism of Stara Planina depends on solving general and preventing environmental problems. The research was carried out on the territory of the local communities of Eastern Serbia,

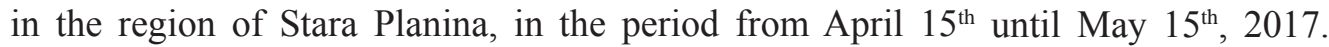
Survey questionnaires were used as a research tool and the number of validly filled questionnaires was 300. The research was anonymous.

As the greatest problems of Stara Planina we have identified:

- Poor road connection

- Local population unemployment

- Aging population

- Low income at the local level

- Ecological problems

As the greatest ecological problems of Stara Planina we have identified:

- Waste water

- Communal waste

- $\quad$ Traffic pollution

- Industrial pollution

This research initiated from the basic hypothesis:

"Solving general and preventing ecological problems on Stara Planina Mountain will significantly improve the development of rural tourism." 
A five-point Likert scale was applied to the gradation of the received responses, and data processing was carried out through the software package SPSS 23.0. Based on the data obtained from descriptive analysis, we have formed determinants that are defined as survey segments. Therefore, several variables are aggregated into one determinant that is the carrier of all information related to the responses of each survey segment, using the arithmetic mean derived from the data on the same scale of measurement. In this way, we have obtained new statistical descriptive parameters that explain the form, distribution and heterogeneity/homogeneity of the data. This is a quantitative continuous random variable - the determinant; thereafter, it is verified if it belongs to the normal distribution of the random variable. For this verification, it was used the universal Kolmogorov-Smirnov statistical test.

After the application of the mentioned test, it was found that the new random variable - determinant does not fulfill the regularity of the random variable distribution, so it was necessary to apply one of the basic transformation methods, so-called "degree" transformation, after which it was repeated entire analytics and exploration for the socalled transformed random variable - determinant.

High heterogeneity has been eliminated by data transformation, so the determinant has the form of the so-called Gaussian bells, as it can be seen from the following tables and charts.

Table 1. Descriptive statistics of the determinants related to solving general problems of Stara Planina Mountain

\begin{tabular}{|c|c|c|c|c|}
\hline \multicolumn{3}{|c|}{ Descriptive statistics } & Statistics & $\begin{array}{c}\text { Post-transformation } \\
\text { statistics }\end{array}$ \\
\hline \multirow{10}{*}{$\begin{array}{l}\text { Solving general } \\
\text { problems }\end{array}$} & \multicolumn{2}{|l|}{ Arithmetic mean } & 3.7827 & 14.8675 \\
\hline & \multirow{2}{*}{$\begin{array}{l}95 \% \text { average trust } \\
\text { interval }\end{array}$} & Low & 3.6977 & 14.2773 \\
\hline & & High & 3.8678 & 15.4578 \\
\hline & \multicolumn{2}{|l|}{ Average mean } & 3.9200 & 15.3664 \\
\hline & \multicolumn{2}{|l|}{ Variations } & 0.560 & 26,988 \\
\hline & \multicolumn{2}{|l|}{ Standard deviation } & 0.74864 & 5.19501 \\
\hline & \multicolumn{2}{|l|}{ Minimum } & 1.37 & 1.88 \\
\hline & \multicolumn{2}{|l|}{ Maximum } & 4.90 & 24.01 \\
\hline & \multicolumn{2}{|l|}{ Asymmetry } & -0.933 & -0.425 \\
\hline & \multicolumn{2}{|l|}{ Equalization } & 0.573 & -0.486 \\
\hline
\end{tabular}

Source: Authors

Table 1 show that the average value of the determinant is 3.7827 , the trust interval ranges from 3.6977 to 3.8678 , with a standard deviation of less than 1, which also shows a moderate heterogeneity of the data. The average minimum value is 1.37 and the maximum is 4.90 . The coefficient of asymmetry and flattening has been partly increased, as it can be seen on the chart of normal frequency distribution, Figure 1.

By the normality test (Table 2) it was verified the validity of the results values for solving the general problems of Stara Planina. Based on the obtained results shown in the table, it was found that the validity for parametric statistical tests has not been fulfilled. After that, it was done the degree transformation, as the first and the basic transformation, http://ea.bg.ac.rs 
and in this way it was obtained a new determinant with an average value of 14.8675 with the trust interval from 14.2773 to 15.4578 , and a standard deviation of 5.19501, where the values of the asymmetry and flattening were reduced, meaning that it fulfills the validity for parametric statistical tests. From the charts in Figure 1 it can be seen that the obtained results are arranged according to the Gaussian curve.

Table 2. Normality test for the result values - solving the general problems of Stara Planina Mountain

\begin{tabular}{|c|c|c|c|}
\hline \multirow{2}{*}{} & \multicolumn{3}{|c|}{ Kolmogorov-Smirnov } \\
\cline { 2 - 4 } & Statistic & df & Sig. \\
\hline Solving general problems & 0.089 & 300 & 0.001 \\
\hline Solving general problems TR & 0.068 & 300 & 0.060 \\
\hline
\end{tabular}

Source: Authors

Figure 1. Normal distribution of frequencies for solving general problems of Stara Planina

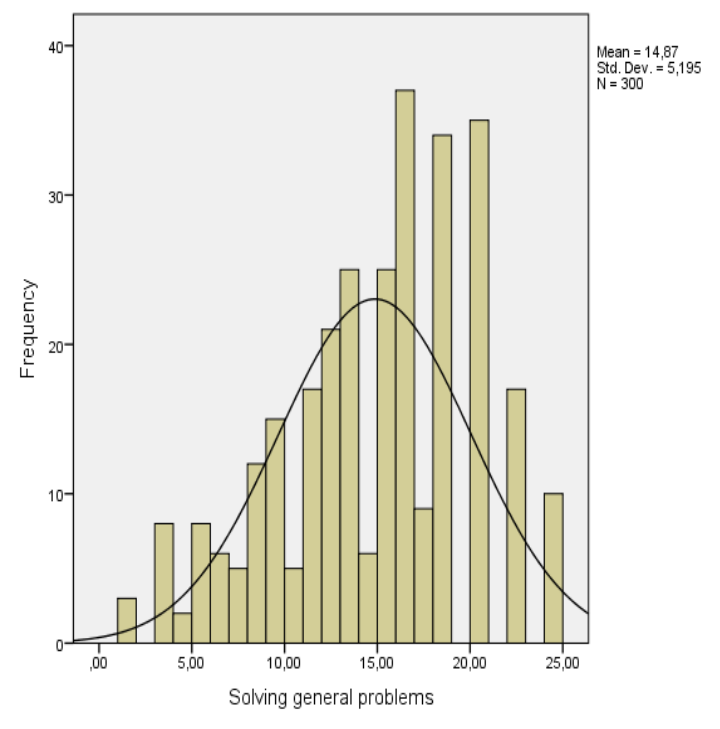

Source: Authors

Table 3 shows that the average value of the determinant is 3.3356 , the trust interval varies from 3.3356 to 3.4223 , with a standard deviation of less than 1, which also shows a moderate heterogeneity of the data. The average minimum value is 1.46 and the maximum is 4.88 . The asymmetry and flattening coefficient is partially increased, as it can be seen on the chart of the normal frequency distribution, Figure 2. 
Table 3. Descriptive statistics of the determinants related to preventing ecological problems of Stara Planina Mountain

\begin{tabular}{|l|l|l|r|r|}
\hline \multicolumn{2}{|c|}{ Descriptive statistics } & \multicolumn{1}{|c|}{ Statistics } & \multicolumn{1}{c|}{$\begin{array}{c}\text { Post-transformation } \\
\text { statistics }\end{array}$} \\
\hline \multirow{4}{*}{$\begin{array}{c}\text { Preventing } \\
\text { ecological problems }\end{array}$} & Arithmetic mean & 3.3356 & 11.7069 \\
\cline { 2 - 5 } & $\begin{array}{l}\text { 95\% average trust } \\
\text { interval }\end{array}$ & Low & 3.3356 & 11.1386 \\
\cline { 2 - 5 } & Average mean & High & 3.4223 & 12.2752 \\
\cline { 2 - 5 } & Variations & 3.4000 & 11.5600 \\
\cline { 2 - 5 } & Standard deviation & 0.583 & 25.016 \\
\cline { 2 - 5 } & Minimum & 0.76343 & 5.00162 \\
\cline { 2 - 5 } & Maximum & 1.46 & 2.13 \\
\cline { 2 - 5 } & Asymmetry & -0.234 & 23.81 \\
\cline { 2 - 5 } & Equalization & -0.637 & -0.218 \\
\hline
\end{tabular}

Source: Authors

With the normality test (Table 4) it was verified the validity of the results obtained for the prevention of the ecological problems of Stara Planina. Based on the obtained results shown in the table it was concluded that the validity for parametric statistical tests has not been fulfilled. After that, it was made the degree transformation, as the first and the basic transformation. In this way it was obtained a new determinant with an average value of 11.7069 in the trust interval from 11.1386 to 12.2752 , with a standard deviation of 5.00162, where the values of the flattening asymmetry were reduced. It shows the fulfillment of the validity for parametric statistical tests and from the charts in Figure 2 it can be seen that the obtained results are arranged according to the Gaussian curve.

Table 4. Normality test for results values - preventing the ecological problems of Stara Planina Mountain

\begin{tabular}{|l|c|c|c|}
\hline \multirow{2}{*}{} & \multicolumn{3}{|c|}{ Kolmogorov-Smirnov $^{\mathbf{a}}$} \\
\cline { 2 - 4 } & Statistic & df & Sig. \\
\hline Preventing ecological problems & 0.086 & 300 & 0.002 \\
\hline Preventing ecological problems TR & 0.066 & 300 & 0.062 \\
\hline
\end{tabular}

Source: Authors 
Figure 2. Normal distribution of frequencies - preventing ecological problem of Stara Planina

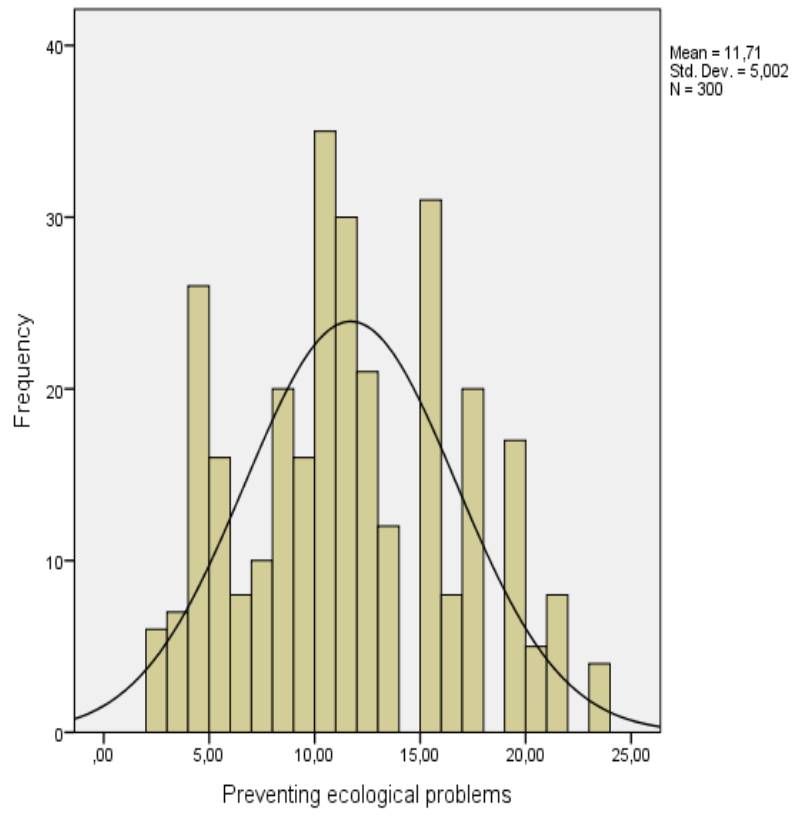

Source: Authors

\section{Results}

For real hypothesis testing there were made two new sets of determinants. Each of them is made of two determinants of similar characters. The problems of the Stara Planina Mountain, as the first set, were sorted into two, general and ecological problems. Consequently, both determinants were taken into account in order to detect which of them can solve the obstacles that prevent the rural tourism development on Stara Planina. The determinants related to the respondents' statements important for the improvement of rural tourism in the area of Stara Planina represent so-called determinants of solving general problems. The determinants related to the respondents' statements important for solving environmental problems in the area of Stara Planina represent so-called determinants of the environmental problems prevention.

Table 5. Descriptive parameters for dependent and explanatory determinant of the first set of determinants

\begin{tabular}{|l|c|c|c|}
\hline \multicolumn{1}{|c|}{ Descriptive parameters } & $\begin{array}{c}\text { Average } \\
\text { value }\end{array}$ & $\begin{array}{c}\text { Standard } \\
\text { deviation }\end{array}$ & Number \\
\hline Improving rural tourism TR & 15.1225 & 5.73778 & 300 \\
\hline Solving general problems TR & 14.8675 & 5.19501 & 300 \\
\hline Preventing ecological problems TR & 11.7069 & 5.00162 & 300 \\
\hline
\end{tabular}

Source: Authors 
Table 5 shows the average values of the first set of determinants after the degree transformation of the average initial scale used for the evaluation in the survey.

Table 6. Coefficients of the multiple correlations between first set of determinants that explain improvement of rural tourism

\begin{tabular}{|c|c|c|c|}
\hline $\begin{array}{c}\text { Simple linear } \\
\text { correlation }\end{array}$ & $\begin{array}{c}\text { Determinant } \\
\text { coefficient }\end{array}$ & $\begin{array}{c}\text { Fixed determinant } \\
\text { coefficient }\end{array}$ & Standard deviation \\
\hline 0.36 & 0.129 & 0.123 & 5.37214 \\
\hline
\end{tabular}

Source: Authors

Table 6 shows that the coefficient of free linear correlation as a relative measure is positive (0.36), suggesting a certain connection between the variables. The determination coefficient is 0.129 , and the corrected determination coefficient is 0.123 . The improvement of rural tourism of Stara Planina depends to a certain extent on solving the general problems, as well as on preventing the ecological ones, and in this case it is almost $13 \%$. This is an important indicator, as it can be seen in the table below. The standard evaluation error for the tested variable is less than the sample error, which indicates the model's justification.

Table 7. Justification of the multiple regression analysis of the model via Anova test

\begin{tabular}{|l|c|c|c|c|c|}
\hline $\begin{array}{c}\text { Justification of } \\
\text { the model }\end{array}$ & $\begin{array}{c}\text { Square } \\
\text { amount }\end{array}$ & df & Square average & F test & $\begin{array}{c}\text { Deviation } \\
\text { probability }\end{array}$ \\
\hline Regression & 1272.309 & 2 & 636.155 & 22.043 & 0.00 \\
\hline Residual & 8571.388 & 297 & 28.860 & & \\
\hline Total & 9843.698 & 299 & & & \\
\hline
\end{tabular}

Source: Authors

Table 7 shows that the multi-correlation coefficient is statistically significant, which means that the percentage of explained positive variation is $13 \%$ and correlates with the explanatory determinant, as confirmed by the statistical $\mathrm{F}$ test.

Table 8. Statistical parameters of the multiple regression model of the first set of determinants

\begin{tabular}{|l|c|c|c|c|c|c|c|}
\hline \multirow{2}{*}{$\begin{array}{c}\text { Statistical } \\
\text { model } \\
\text { parameters }\end{array}$} & \multicolumn{2}{|c|}{$\begin{array}{c}\text { Non-standard } \\
\text { coefficients }\end{array}$} & $\begin{array}{c}\text { Standard } \\
\text { coefficients }\end{array}$ & \multirow{2}{*}{$\mathbf{t}$} & \multicolumn{2}{c|}{$\begin{array}{c}\text { Probability } \\
\text { of error }\end{array}$} & \multicolumn{2}{|c|}{ Mutual collinearity } \\
\cline { 2 - 5 } \cline { 6 - 8 } & B & Std. error & Beta & & & Tolerance & VIF \\
\hline Constant & 8.553 & 1.037 & & 8.248 & 0.000 & & \\
\hline $\begin{array}{l}\text { Solving } \\
\text { general } \\
\text { problems }\end{array}$ & 0.284 & 0.064 & 0.258 & 4.432 & 0.000 & 0.868 & 1.152 \\
\hline $\begin{array}{l}\text { Preventing } \\
\text { ecological } \\
\text { problems }\end{array}$ & 0.200 & 0.067 & 0.174 & 3.000 & 0.003 & 0.868 & 1.152 \\
\hline
\end{tabular}

Source: Authors 
Table 8 shows that the partial coefficients of the multiple regression of the segment of dependent determinants and the inclination of the explanatory determinant are statistically significant, as it can be seen from the $t$ test statistics, because they are greater than the table values with a probability of error of less than 0.05. Based on standardized Beta coefficients, it can be concluded that solving general problems has a higher priority than preventing environmental problems, as indicated by a higher Beta coefficient.

\section{Conclusions}

The protection of the environment on Stara Planina Mountain is a serious problem, because a large number of visitors are not willing to protect the natural environment. According to the conducted research, the biggest ecological problem at the destination of Stara Planina is communal waste, as well as the wastewater. According to this survey, responsibility for these problems lies with the municipality and environmental polluters. Therefore, it is necessary to take appropriate environmental protection measures in this area, which represents the most important segment of tourism business. Environmental protection affects the quality of life, with a tendency to be more significant in the future.

The development of rural tourism on Stara Planina significantly depends on the solutions of general problems, the most prominent of which is the unemployment of the local population. Also, the development of tourism depends on the prevention of the environmental problems of Stara Planina, among which the problem of waste water and communal waste are the most serious. Based on the statistical tests, it can be concluded that solving general problems has a higher priority compared to the prevention of environmental problems, as indicated by the statistical parameters of the multiple regression model of the first set of determinants.

Based on the results obtained in this research, the hypothesis that initiated this research has been proven, which also means that the improvement of rural tourism on Stara Planina depends on solving general and preventing environmental problems.

\section{Conflict of interests}

The authors declare no conflict of interest.

\section{References}

1. Gašić, M., Madžgalj, J., Ivanović, V., \& Perić, G. (2015). The impact of rural tourism on local economic development, Ecologica, 22(77), 32-36. [in Serbian: Гашић, М., Маџгаљ, Ј., Ивановић, В., \& Перић Г. (2015), Утицај руралног туризма на локални економски развој].

2. Gašić, M., Stojković, A., \& Simić, J. (2013). Perspectives of tourism development in the area of Toplički district. Ekonomika, 59(3), 187-199. [in Serbian: Гашић, М., Стојковић, А., \& Симић, J. (2013), Перспектива развоја туризма на простору Топличког округа]. 
3. Živković, B. (2013). Economic aspects of the impact of tourism on the economy of rural regions, Ecologica. 20(71), 541-544. [in Serbian: Живковић, Б. (2013), Економски аспекти утицаја туризма на економију руралних регија].

4. Jovičić, D. (2002). Management of tourist destinations, Želnid, Beograd. [in Serbian: Јовичић, Д. (2002), Мемаџмент туристичких дестинација].

5. Kostić, M., Knežević, G., \& Vukadinović, P (2014). Environment and sustainable development, Ecologica, 21(73), 93-96. [in Serbian: Костић, М., Кнежевић, Г., \& Вукадиновић, П. (2014), Животна средина и одрживи развој].

6. Maksimović, M., Urošević, S., \& Mihajlović, D. (2015). The effects of the development of rural tourism on Stara Planina, Eкonomika, 61(2), 83-92.

7. Maksimović, M., Urošević, S, \& Mihajlović, D. (2015a). From the mining areas to the tourist destination space of Stara planina mountain, Rudarski radovi, (1), 33-46.

8. Maksimović, M., Urošević, S., \& Mihajlović, D. (2015b). Strategic directions of the development of rural tourism in Stara planina, Ecologica, 22(78), 233-238. [in Serbian: Максимовић, М., Урошевић, С., \& Михајловић, Д. (2015b), Стратешки правци развоја руралниг туризма Старе планине].

9. Marković, S., Pejanović, Lj. (2012). Environmental protection in sustainable development policy. Faculty of Legal and Business Studies, Novi Sad. [in Serbian: Марковић, С., Пејановић, Љ. (2012), Заштита животне средине у политици одрживог развоја].

10. Mladenović A. (2015). Analytical method for monitoring soil contamination through the elements of the presence of heavy metals in the municipality Zajecar, Fifth international symposium on natural resources management, pp.329-334.

11. Miletić S., Paunković J., Đurić M., Bogdanović D. (2015). Implemation of MCDM methods in suistainable development, $10^{\text {nd }}$ International Symposium on Recycling Technologies and Sustainable Development, pp. 100-108.

12. Muhi B., (2013). Rural tourism as a component of the regional and sustainable development of villages in Vojvodina, Proceedings, Matice srpske za društvene nauke, (142), 129-137. [in Serbian: Мухи, Б. (2013), Рурални туризам као компонента интегралног одрживог развоја села у Војводини].

13. Nikolić Đ., Spasić J., Živković Ž., Đorđević P., Mihajlović I., \& Kangas J. (2015). SWOT - AHP model for prioritzation of strategies of the resort Stara planina, Serbian Journal of Management, 10(2), 1-10.

14. Ruhanan, L. (2012). Developing a strategic vision: integration principles of sustainable development in planning tourist destinations, Acta Turistica, 24(2), 149-176. 
15. Petroman, I., Amzulescu, O., Sărăndan, H., Petroman, C., Coman, S., Orboi, D.M., \& Ivu, M. (2010). Blue Flag: a Symbol of Environmental Protection. Animal Science and Biotechnologies, 43(2), 426-428.

16. Jovičić D. (2000). Tourism and the environment. Zadužbina Andrejević, Beogpad. [in Serbian: Јовичић, Д. (2000), Туризам и животна средина].

17. Popesku J. (2002). Marketing in tourism, Čigoja, Beograd. [in Serbian: Попеску, J. (2002), Маркетинг у туризму].

18. Vollenbroek, F. A. (2002). Sustainable development and the challenge of innovation, Journal of Cleaner Production, (10), 215-223.

19. Kalač, N. (2013). Strategic directions for the development of rural tourism in Rožaje, Ekonomski izazovi, 2(4), 132-150. [in Serbian: Калач, Н. (2013), Стратешки правци развоја руралног туризма у Рожајима].

20. Sanagustín Fons, M., Moseñe Fierro, A., \& Gómez y Patiño, M. (2011). Rural tourism: A sustainable alternative, Journal Applied Energy (88), 551-557.

21. Stankov, U., Stojanović, V., Dragićević, V., \& Arsenović, D. (2010). Ecotourism - an alternative to mass tourism in the nature park "Stara Planina", Proceedings of the Geographical Institute ,,Jovan Cvijic“ “ SANU 61(1), 41-58. [in Serbian: Станков, У., Стојановић, В., Драгићевић, В., \& Арсеновић, Д. (2010), Екотуризам-алтернатива масовном туризму у парку природе „Стара планина“"].

22. Unković S., Zečević B. (2006). Economics of tourism, Faculty of Economics, Belgrade. [in Serbian: Унковић, С., Зечевић, Б. (2006), Економика туризма].

23. Vehbi O.B., (2012). A Model for Assessing the Level of Tourism Impacts and Sustainability of Coa stal Cities, Strategies for Tourism Industry - Micro and Macro Perspectives, Dr. Murat Kasimoglu (Ed.), pp. 99-114. 